\title{
Percursos migratórios intergeracionais e dinâmicas de implantação de imigrantes estrangeiros no oeste paulista (1880-1950) ${ }^{1}$
}

\author{
Oswaldo Mario Serra Truzzi ${ }^{\star}$ \\ https://orcid.og/0000-0002-9046-5092 \\ João Pedro Volante* \\ https://orcid.org/0000-0001-8306-3629
}

\begin{abstract}
Toda regiäo pioneira éessencialmente marginal, incerta e fugitiva. Isso torna sem dívida dificil sua cartografia exata, mas o valor de seu estudo reside precisamente no conhecimento de uma sociedade em movimento. PIERRE MONBEIG, em artigo publicado nos Annales d' Histoire Économique et Sociale, $1937^{2}$.
\end{abstract}

Introdução

Estudos migratórios no interior paulista têm como padrão analisar um determinado grupo étnico em uma determinada localidade 3 . Sem negar a importância de tais estudos, é preciso, no entanto, reconhecer que tais trabalhos normalmente captam uma imagem artificialmente estática da realidade. Estática no sentido de que em geral pressupõem que as famílias constituintes de um determinado grupo étnico sempre estiveram naquela localidade desde que realizaram a migração transatlântica, quando

* Universidade Federal de São Carlos, São Paulo, Brasil.

1. Este artigo foi desenvolvido com o apoio da Fapesp no âmbito do projeto "Percursos histórico-sociais na incorporação de imigrantes estrangeiros no oeste paulista, 1880-1950” (projeto 2015/20577-6) e do CNPq (processo 308322/2018-5).

2. Pierre Monbeig: geógrafo francês que trabalhou na Universidade de São Paulo e estudou o Brasil entre 1935 e 1946.

3. Entre muitos outros exemplos, consultar Leite (2007), Oliveira, (2002), Coelho (2005) e Oliveira (2008). 
na verdade elas normalmente se movimentaram com certa frequência muito antes de se estabelecerem em áreas - sejam urbanas ou rurais - de um determinado município.

O uso intensivo, como fonte, dos próprios censos demográficos realizados no estado de São Paulo em diferentes épocas (Bassanezi et al., 2008) contribui para cristalizar tal situação, pois o que são estes, se não fotografias (estáticas, portanto, e não filmes, dinâmicos) a captar um determinado estado de coisas relativamente a uma população? (Sauvy, 1970, p. 12). Como indicou Álvaro Vieira Pinto, referindo-se à complementaridade entre as duas principais fontes demográficas - censos e registros civis - "se o dado censitário aparece como uma imagem estática, é em verdade, a imagem estática de uma realidade efetivamente móvel, de um processo que se desenvolve no tempo e no espaço, movido por determinantes internos e refletindo em suas fases a lei lógica que o governa” (Pinto, 1973, p. 109).

A análise das trajetórias familiares de imigrantes no oeste paulista ${ }^{4}$ nos impele à investigação de um padrão social distinto de acomodação das famílias ao território. No extremo oeste, por exemplo, são relativamente raras as famílias que ali se instalaram chegadas diretamente da Europa ou da Ásia. Temos então que reconhecer a existência de uma fronteira em contínua expansão no território paulista, que significou também uma contínua mobilidade das famílias imigrantes.

Dado tal contexto dinâmico de deslocamento progressivo da frente pioneira (desenvolvido na primeira parte do texto), a questão que se coloca, cuja resposta constitui o objetivo do presente artigo, é: Do que dependeu a implantação geográfica inicial e mobilidade espacial frequente dos diversos contingentes de imigrantes que se estabeleceram no interior paulista?

O tema em questão, de natureza interdisciplinar por excelência, resvala em terrenos da história, geografia e demografia. Porém, de um ponto de vista sociológico, tais questões remetem à investigação da racionalidade das ações sociais (no que tange tanto a fins, quanto a valores) subjacentes a tais fenômenos (como se procurou analisar na segunda parte do texto). Para tanto, propôs-se o conceito de percursos migratórios familiares intergeracionais, que busca justamente captar, por meio de pesquisa bibliográfica e de entrevistas realizadas, a lógica propriamente social (porque vivenciada e agenciada por indivíduos e famílias) de implantações, deslocamentos e permanências de imigrantes estrangeiros ao longo do território paulista.

4. Aqui definido como a porção do território paulista acima do Trópico de Capricórnio (o que exclui a capital e regiões litorâneas), bem como municípios do Vale do Paraíba pelos quais a cultura do café, tocada a braço escravo e originária de terras fluminenses, penetrou pioneiramente na primeira metade do século xix. Observe-se ainda que a lavoura do café pouco se desenvolveu em latitudes abaixo do Trópico de Capricórnio, dada a ocorrência mais frequente de geadas ou a qualidade inferior dos solos. 
Uma fronteira em contínua expansão

O processo de incorporação crescente de terras a uma agricultura de exportação (no caso, o café), ou, em outras palavras, uma fronteira agrícola em contínua expansão em direção a oeste, condicionou o assentamento progressivo de famílias imigrantes. Tal fenômeno ocorreu segundo várias condições e etapas, a seguir descritas de modo sumário.

Terras como recurso abundante, clima e solos favoráveis

A primeira condição foi que o estado de São Paulo contava com terras ainda inexploradas, de excelente qualidade, cujos solos e clima temperado se prestavam a uma agricultura de exportação como o café, produto cuja demanda crescia exponencialmente nos mercados europeu e norte-americano. O Almanaque Literário da Provincia de São Paulo, publicado em 1878 pelo jornalista português radicado no Brasil José Maria Lisboa, ilustra de modo exemplar a ampla disponibilidade de "terrenos desconhecidos" com que contava o estado na época.

FIGURA 1

Carta da Provincia de São Paulo, 1878

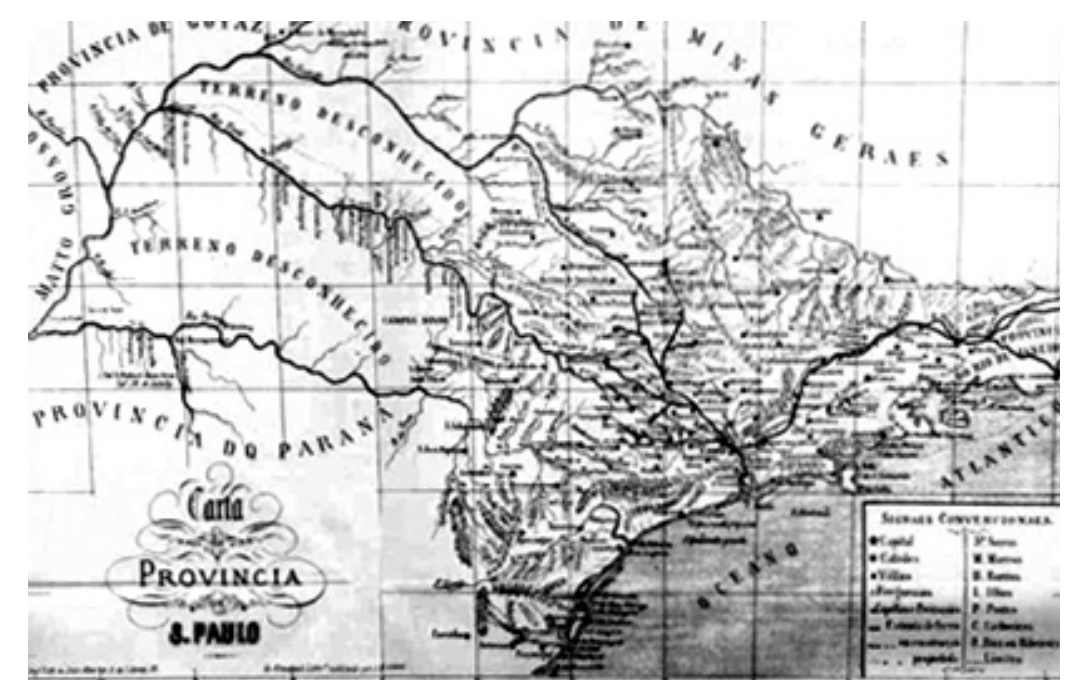

Fonte: Almanaque Literário da Província de São Paulo, 1878.

Poucos anos depois, por ocasião do censo de 1886, um mapa da província se referia a "terrenos despovoados" na região oeste do estado. Observe-se ainda que ambas as expressões - terrenos desconhecidos ou terrenos despovoados - correspondem a extensões de terra certamente menores que o total de terras ainda inexploradas com fins agrícolas no estado. Outros estados podiam dispor de um volume de terras até 
maior que o estado de São Paulo, mas não reuniam necessária e simultaneamente nem qualidade de solos propícios e tampouco clima adequado ao desenvolvimento da cultura do café, dadas as condições tecnológicas da época.

Expulsão, afastamento progressivo ou matança dos índios que habitavam originalmente as terras desconhecidas

Os agentes principais desse processo foram aventureiros que buscavam estabelecer posses de terras em regiões distantes do então chamado "mundo civilizado". Não raro tais contingentes eram constituídos por indivíduos então considerados marginais, forasteiros, ou mesmo escravos fugidos que se estabeleciam em regiões relativamente inóspitas e passavam a viver da caça, de cultivos de subsistência e da criação extensiva de animais, após o desmate de certo terreno. Tais indivíduos também forneciam pouso e abasteciam tropas de mineiros e exploradores que rumavam para Goiás e Mato Grosso, ou de soldados para a Guerra do Paraguai (1864-1870).

Na historiografia paulista, Pierre Monbeig (1984) os chamou de precursores e estes podiam advir tanto de municípios mais antigos do estado, em geral integrantes do chamado "quadrilátero do açúcar" (área interna delimitada pelo polígono formado pelas cidades de Sorocaba, Piracicaba, Mogi-Guaçu e Jundiaí), quanto de áreas mineradoras decadentes do vizinho estado de Minas Gerais 5 .

A título de exemplo, pode-se citar o personagem considerado o fundador de Araraquara, Pedro José Neto, posseiro que se instalou na região com sua mulher, dois filhos e um agregado na primeira década do século XIX. Sem grandes posses - até 1812 não possuía sequer escravos, somente no recenseamento de 1813 ele aparece como proprietário de quatro escravos, diminuídos para dois em 1814-, com o tempo passou a conhecer detalhadamente a região e solicitou uma carta de sesmaria, que deveria ser avalizada pela Câmara de Itu, de onde provinha. Pedro acabou obtendo uma carta de sesmaria, mesmo que relativamente modesta, porque, mesmo sendo de origem humilde, pôde intermediar o conhecimento que tinha da região com fazendeiros mais poderosos da Vila de Itu, que justamente dominavam a Câmara. Estes logo se valeram das informações que Pedro acumulara sobre a região, requereram e assim obtiveram cartas de sesmaria, estas, porém, bem mais extensas que a concedida a Pedro (Truzzi e Follis, 2012, pp. 31-40).

$\mathrm{Na}$ condição de precursores, outros posseiros menos bem-sucedidos interagiam com indígenas que habitavam regiões interioranas do estado de São Paulo, seja de

5. Não por acaso, foram mineiros os fundadores de um conjunto numeroso de municípios do oeste paulista, dentre os quais talvez os mais expressivos sejam Ribeirão Preto, Barretos e São José do Rio Preto. 
modo conflituoso, seja procriando com suas mulheres e gerando daí uma população denominada de cabocla.

\begin{abstract}
Os posseiros favoreceram em grande medida a posterior expansão das lavouras comerciais de cana e depois do café pelo interior paulista. Foram eles os primeiros a desbravar os sertões, tornando-os conhecidos. Além disso, ao serem expulsos das terras já desbravadas e empurrados cada vez mais para o interior de São Paulo, acabaram comprimindo os indígenas em direção ao sertão, atuando como amortecedores de conflitos entre estes e os formadores de grandes fazendas (Truzzi e Follis, 2012, p. 39).
\end{abstract}

O sociólogo José de Souza Martins também caracterizou tais indivíduos posseiros como integrantes do que denominou frente de expansão. Contudo, a principal característica dos precursores (Monbeig) ou da chamada frente de expansão (Martins) é que tais contingentes raramente contavam com recursos que lhes pudessem depois garantir a propriedade de suas posses, como fez Pedro José Neto. Desse modo, tiveram que depois "negociar sua presença”, quando estratos sociais mais poderosos passaram a se interessar por terras ainda incultas, localizadas mais a oeste do estado. Quando não eram incorporados como agregados das futuras propriedades rurais que viriam a se estabelecer, eram simplesmente expulsos para zonas mais distantes, resultando num deslocamento progressivo da frente de expansão.

\title{
A frente pioneira avança sobre a frente de expansão, favorecida pela expansão ferroviária
}

A promulgação da Lei de Terras em 1850, o declínio do regime escravista (com consequente liberação de recursos advindos da desmobilização de plantéis de escravos) e, sobretudo, a crescente expansão da lavoura cafeeira despertaram o interesse de fazendeiros em ocupar novos territórios no interior paulista. Ocorreu então o deslocamento geográfico dos investimentos de famílias proprietárias de terra que já eram afazendadas em municípios mais próximos à capital ou que eram provenientes da vizinha província de Minas Gerais (Bacellar, 1999). Houve a implantação de propriedades rurais por indivíduos ou famílias com recursos variados: cartas de sesmarias (até então não ocupadas); poder político e econômico (por exemplo, para comprar papéis e obter escrituras de terras, ou adquirir terras ainda pouco valorizadas, ou ainda ocupar e estender domínios para terras ainda devolutas); armas para ameaçar, forçar a venda ou expulsar antigos posseiros (da frente de expansão) e se defender.

José de Souza Martins (1996) designou este conjunto como frente pioneira: indivíduos ou famílias proprietárias, capazes de se apropriarem da terra por meios diversos, e de a defenderem, convertendo-a em valor em um mercado de terras ativo. 
FIGURA 2

A evolução ferroviária de São Paulo (1870-1940)

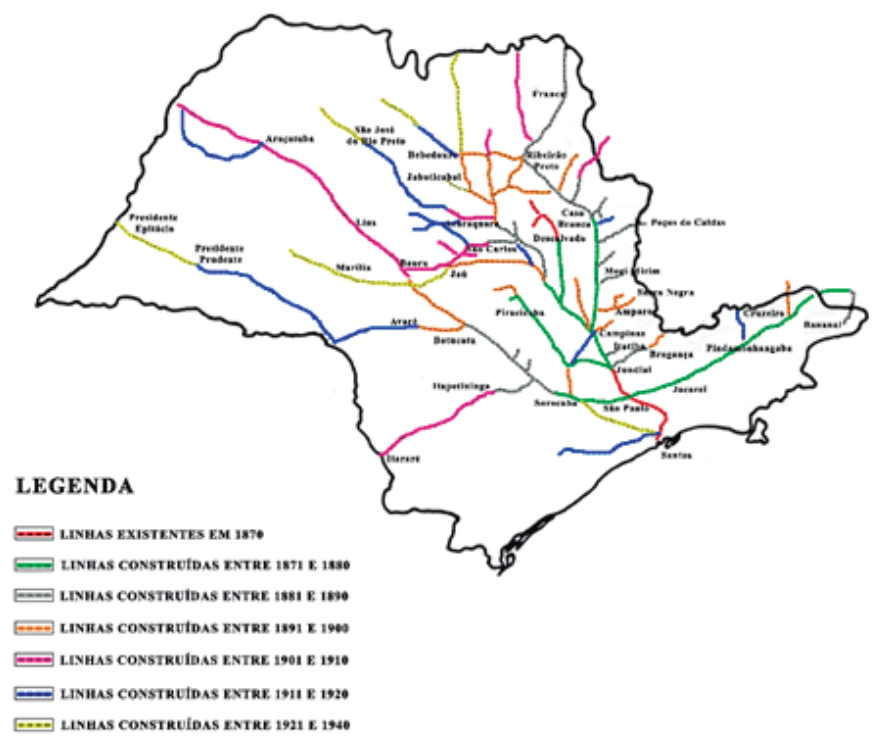

Fonte: Adaptado de Matos (1974).

As terras mais a oeste do estado se valorizaram à medida que a fronteira se tornou economicamente viável. Neste processo a expansão da malha ferroviária paulista jogou um papel essencial. Elas viabilizaram - porque tornaram rentável - a exploração econômica de áreas antes desconectadas da exploração agrícola para o mercado mundial, via porto de Santos. A chegada da estrada de ferro a Jundiaí

[...] era um marcado e significativo degrau na evolução progressiva da cultura do café e das atividades rurais em geral, como do povoamento do hinterland do Oeste. De fato, a ferrovia, avançando, oferecia transporte aos produtos da lavoura, por preços, em média, dez vezes mais baixos dos que até então vigorantes, efetuados no dorso do muar. É claríssimo que, com isso, o raio, dentro do qual o café poderia ser produzido e exportado, poderia ser alongado e dilatada a área, comportando lavouras de café” (Ellis Jr., 1960, p. 177).

Antes de serem implantadas as ferrovias, houve, portanto, um movimento especulativo de terras antecipando e vislumbrando a viabilidade da exploração comercial agrícola graças à integração da nova zona em um circuito de comercialização mundial. As famílias de posses, constitutivas da frente pioneira, normalmente se anteciparam à chegada da ferrovia e, vislumbrando vantagens no futuro (seja para especular com 
terras, seja para efetivamente desenvolver a produção cafeeira), procuraram adquirir, ocupar ou tomar posse de terras, nelas implantando propriedades rurais.

O historiador Alfredo Ellis Jr. forneceu uma descrição interessante (embora autoglorificante) deste processo ao biografar a trajetória de Francisco da Cunha Bueno (1830-1903), seu avô. Inicialmente afazendado em Indaiatuba, este se deslocou para abrir novas fazendas em Rio Claro, depois em Itaqueri (atual Itirapina) e finalmente em Santa Eudóxia, ao norte do município de São Carlos. Em cada uma dessas empreitadas, sempre se antecipou em vários anos à chegada da ferrovia, para que as terras fossem adquiridas a um preço melhor, a fazenda fosse formada e a lavoura de café entrasse em produção em tempo oportuno (Ellis Jr., 1960).

No estado de São Paulo, as ferrovias normalmente perseguiram a ocupação do território, mas em algumas zonas, como no exemplo da E. F. Noroeste, chegaram a precedê-la. Nesse caso, os trabalhadores que construíram e implantaram a ferrovia em certa medida fizeram o papel da frente de expansão, dizimando ou deslocando a população indígena que originalmente habitava o território (Carvalho, 1974).

\section{0 deslocamento sucessivo da frente pioneira e a derrocada do regime escravista exigem a importação de imigrantes}

Com a aproximação da abolição e também após esta, a expansão do cultivo de café em zonas recém-abertas dependia da importação de mão de obra imigrante, fosse para abrir e trabalhar novas terras, fosse para substituir escravos em propriedades mais antigas. Os fazendeiros paulistas optaram por trazê-los da Europa e, a partir de 1908, também do Japão. Finalmente entra então em cena nosso protagonista principal, o imigrante estrangeiro.

Observe-se, porém, que, em todo o processo acima descrito, subjaz um contexto essencial que receberá os imigrantes estrangeiros: o de um estoque de terras disponíveis e de uma fronteira agrícola em contínua expansão que encerra em si uma dinâmica própria, mediada pelos avanços sucessivos da frente de expansão (posseiros) e da frente pioneira (proprietários).

Um exercício interessante é tentar vislumbrar graficamente como evoluiu historicamente no estado paulista a frente pioneira. Para tanto, tomamos como aproximação ${ }^{6}$ os núcleos urbanos mais a oeste do estado em diferentes épocas nas quais recenseamentos foram realizados. Em 1854, por exemplo, conforme ilustra

6. Trata-se de uma aproximação, porque obviamente a frente pioneira, delineada pela apropriação de terras por meios diversos, mas agora valoradas em um mercado de terras ativo (como já se observou acima), sempre se situará um pouco mais adiante da linha delineada pelos últimos núcleos urbanos criados a oeste. 
FIGURA 3

Frente pioneira e população estrangeira por município, 1854

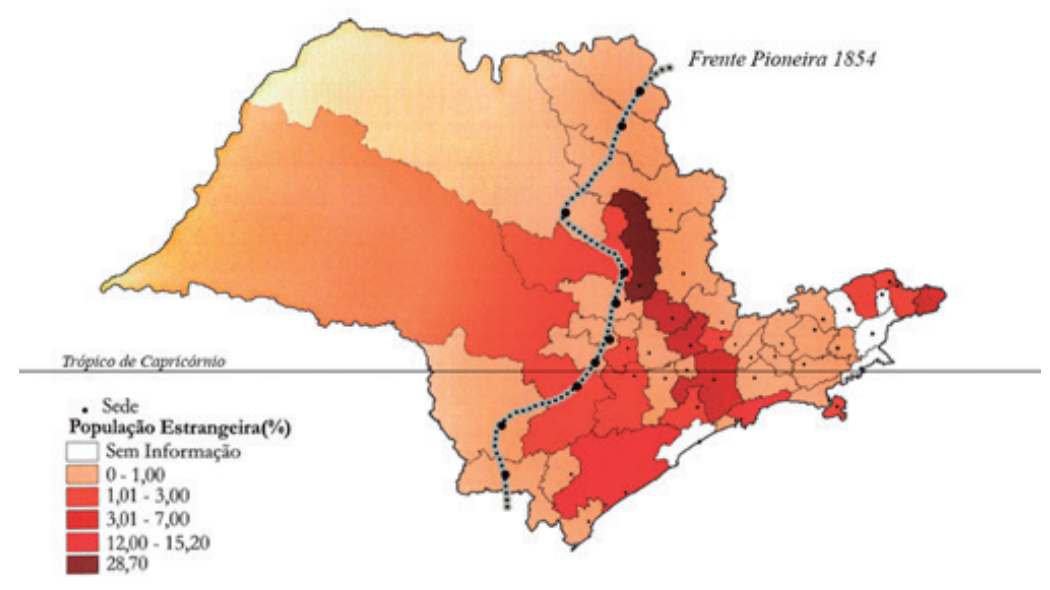

Fonte: Adaptado de Bassanezi et al. (2008).

FIGURA 4

Aproximação da frente pioneira e população estrangeira por município, 1886

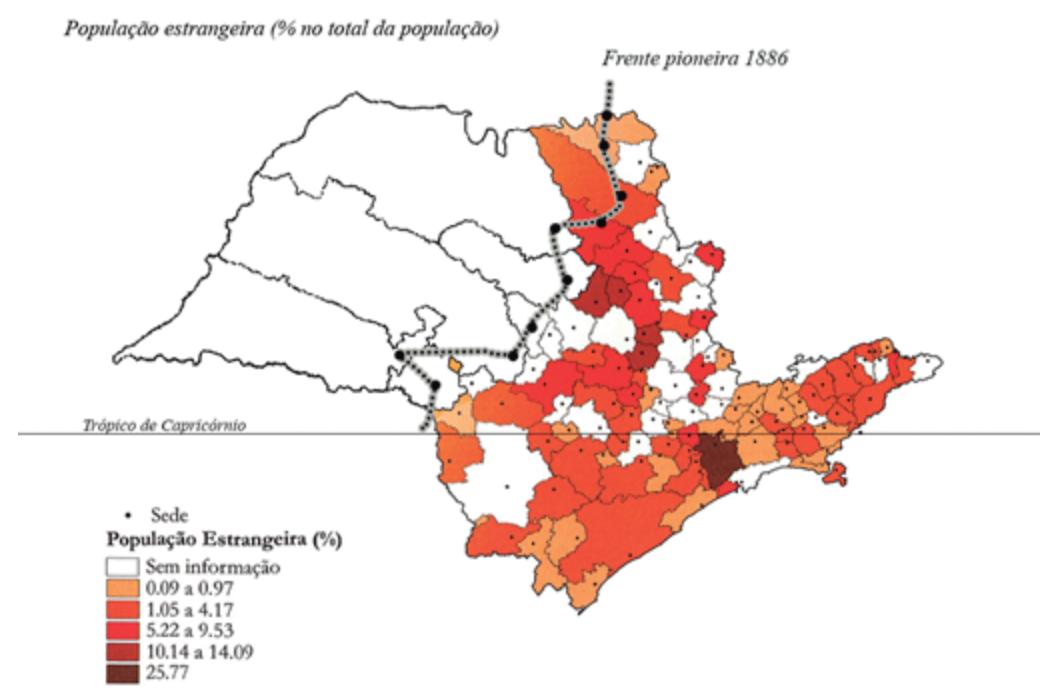

Fonte: Adaptado de Bassanezi et al. (2008). 
FIGURA 5

Aproximação da frente pioneira e população estrangeira por municipio, 1920

Populaçâo estrangeira ( $\%$ no rotal da populaçâo)

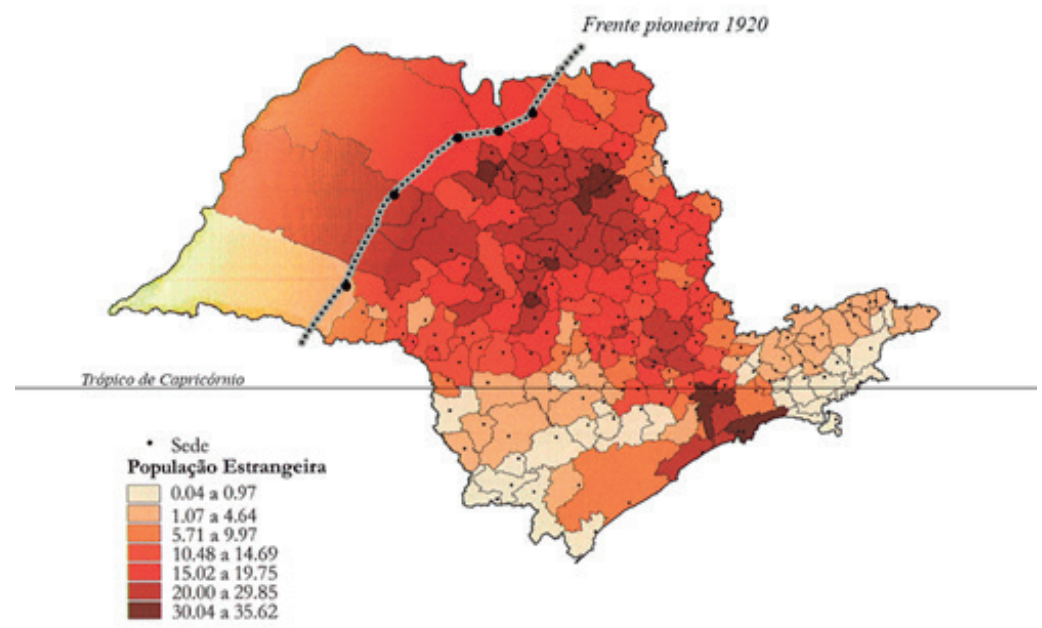

Fonte: Adaptado de Bassanezi et al. (2008).

a Figura 3, os núcleos urbanos mais a oeste delineavam a frente (do norte ao sul) composta pelos municípios de Franca, Batatais, Araraquara, Rio Claro, Piracicaba, Tietê, Tatuí, Itapetininga, Itapeva e Apiaí7.

Dezoito anos depois, o censo de 1872 captou que a frente havia se deslocado para o oeste $^{8}$, ao passo que no censo seguinte, realizado em 1886, a frente se desloca um pouco mais, agora delineada pelos núcleos de Igarapava, Ituverava, Batatais, Ribeirão Preto, Jaboticabal, Araraquara, Jaú, Lençóis Paulista, Campos Novos Paulista e Santa Cruz do Rio Pardo (Figura 4).

Saltando 34 anos para frente, chegamos ao censo de 1920. Nessa época, a frente pioneira já se deslocara consideravelmente, para ser formada pelos núcleos de Barretos, Olímpia, São José do Rio Preto, Penápolis e Conceição do Monte Alegre (Figura 5).

7. Para a representação gráfica das frentes pioneiras no presente artigo, foi utilizado o software editor e criador de imagens Adobe Photoshop (versão cs6), com a ferramenta "caneta de forma livre", a qual possibilita um traçado de linhas pontilhadas a partir de pontos estabelecidos no mapa, sendo estes - neste caso - os núcleos urbanos localizados mais a oeste no território paulista nos anos de 1854, 1872, 1886, 1920, 1934, 1940 e 1950, quando foram realizados os censos. Optou-se por utilizar essa ferramenta, pois a mesma possibilita a construção de uma curva aproximativa e, também, devido ao fato de os autores terem como objetivo representar as frentes pioneiras como sendo traçados não retilíneos e em constante modificação.

8. Composta agora pelos municípios de Franca, Batatais, Ribeirão Preto, Jaboticabal, Araraquara, Jaú, Lençóis Paulista e Itaporanga. 
FIGURA 6

Aproximação da frente pioneira e população estrangeira por município, 1950

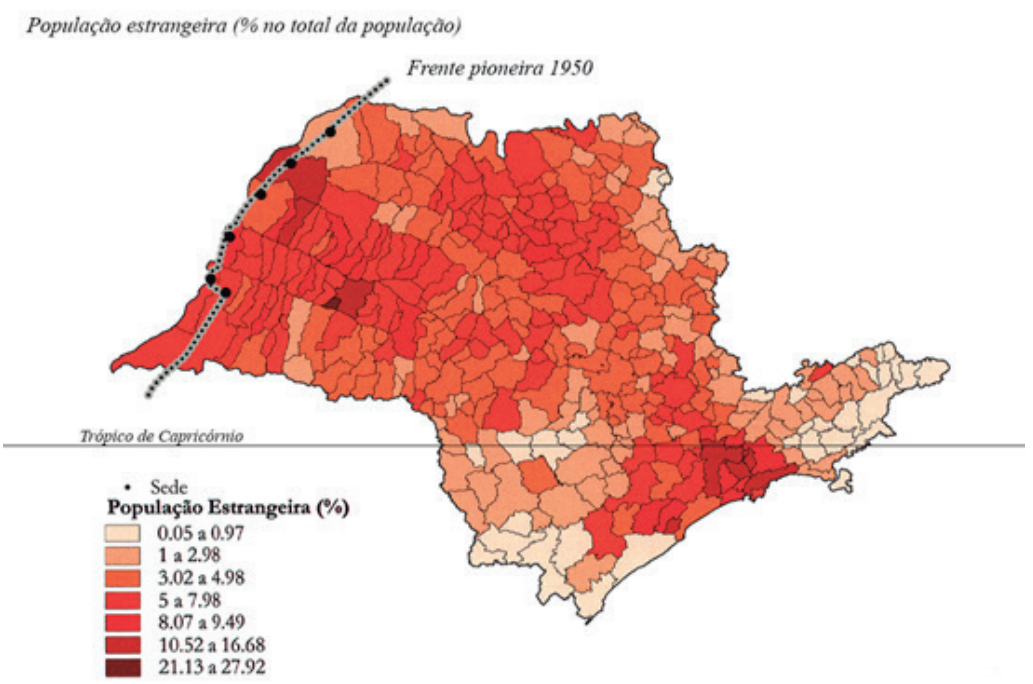

Fonte: Adaptado de Bassanezi et al. (2008).

\section{FIGURA 7}

Avanço das frentes pioneiras (1854, 1886, 1920 e 1950)

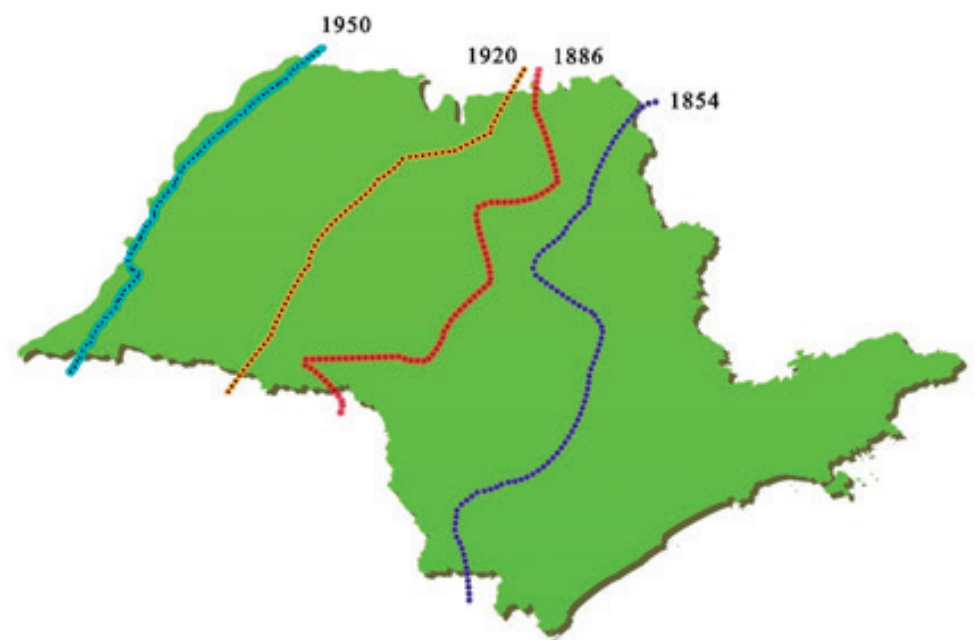

Fonte: Elaboração própria.

Ao serem realizados o censo estadual paulista de 1934 e, seis anos depois, o censo nacional de 1940, a frente segue se deslocando no sentido oeste do estado?.

9. Em 1934 esta era formada pelos municípios de Tanabi, Monte Aprazível, Araçatuba e Presidente Venceslau, e, em 1940, desloca-se um pouco mais em sua porção central, para incluir, além dos municípios extremos de Tanabi e Presidente Venceslau, também os de Pereira Barreto e Andradina. 
FIGURA 8

Distribuição da produção de café (@) em São Paulo, 1904-1905 e 1934-1935
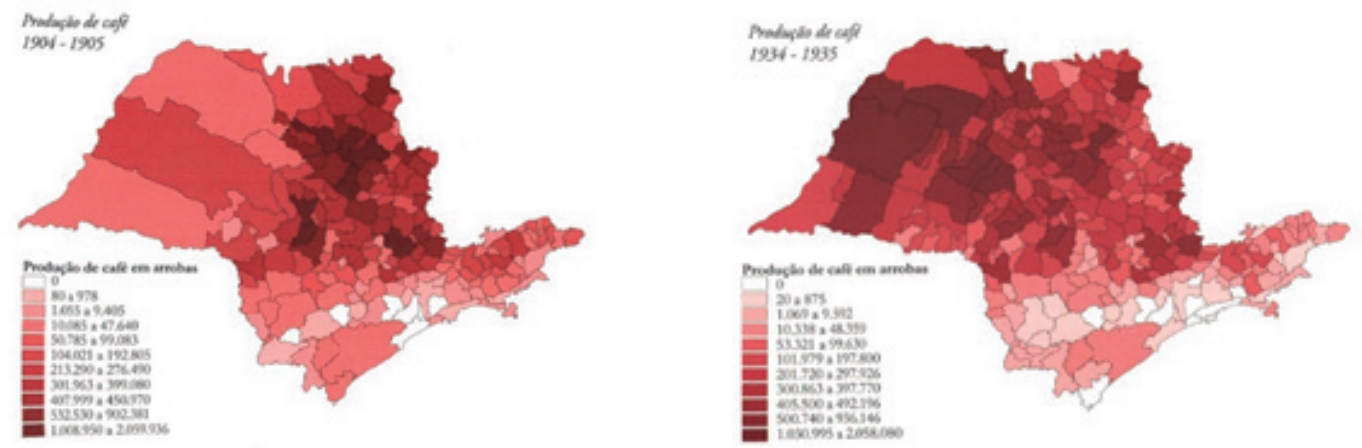

Fonte: Bassanezi et al. (2008).

Por fim, em 1950, o estado de São Paulo já se encontra praticamente ocupado, com a frente formada pelos municípios de Jales, Pereira Barreto, Andradina, Pauliceia, Presidente Epitácio e Presidente Venceslau (Figura 6).

Reitere-se que se trata tão somente de uma aproximação conservadora (no sentido de que as frentes pioneiras reais em cada período com certeza se situavam mais a oeste das linhas acima demarcadas) que leva em conta justamente o surgimento progressivo de novos núcleos urbanos a oeste do estado, com o objetivo de simular o avanço da frente pioneira. O interesse de tal simulação é justamente observar o caráter dinâmico do deslocamento da frente pioneira no estado, conforme ilustra a Figura 7.

É oportuno ainda se notar que o avanço das frentes pioneiras guarda certa aproximação com os mapas da marcha do café no estado de São Paulo, elaborados por Sergio Milliet em seu livro Roteiro do café e outros ensaios, publicado originalmente em 1935, e, quatro décadas depois, por Odilon Nogueira de Matos em seu livro Café eferrovias: a evolução ferroviária de São Paulo e o desenvolvimento da cultura cafeeira, publicado originalmente em 1974.

Campinas encontra o apogeu de suas lavouras na década de 70, e a partir deste município, os trilhos da ferrovia que beneficiavam enormemente o escoamento da produção se bifurcavam em duas frentes: a primeira em direção ao norte da capital, conformando a região da Mogiana, e a segunda em direção ao centro do estado, servido pela Companhia Paulista [...]. Em 1920, e mais ainda em 1934, a produção de café se desloca mais a oeste, atingindo novas áreas. Nesse processo, à medida que o café avança, municípios antigos e enormes são desmembrados, dando origem a uma série de novos municípios. (Bassanezi et al., 2008).

Uma comparação mais recente entre as áreas de produção cafeeira em 1905 e 1935 também ilustra com propriedade como as plantações mais produtivas efetivamente se deslocaram rumo ao oeste do estado (Figura 8). 
Dinâmica de implantação de estrangeiros no território e percursos migratórios intergeracionais

A recolha de trajetórias familiares observadas entre vários grupos étnicos nos sugere um modelo dinâmico no qual pelo menos seis processos concomitantes atuaram.

\section{Timing (anterioridade) de chegada}

De modo geral, entre os grupos que vieram ao interior paulista, aqueles que chegaram mais tarde, tiveram que se estabelecer em zonas mais a oeste, mais distantes da capital. $\mathrm{O}$ caso paradigmático é quando comparamos italianos e japoneses, os primeiros chegados em massa entre a véspera da abolição e 1902, e os segundos a partir de 1908. Não resta dúvida de que os japoneses, proporcionalmente, se concentraram bem mais a oeste que os italianos, pois, enquanto a chegada massiva destes ocorreu já na última década do século XIX, os anos 1930 constituíram a década na qual o fluxo de japoneses foi mais intenso. Tal fato pode ser observado pela distribuição dos dois grupos no oeste paulista. No censo de 1920, a maior parte dos doze municípios que mais abrigavam italianos encontrava-se nas regiões servidas pelas Companhias Paulista e Mogiana. No censo de 1934, a maior parte dos que acolheram japoneses situava-se nas áreas servidas pelas Companhias Noroeste e Sorocabana. Enquanto Ribeirão Preto e Campinas eram os dois municípios do interior do estado que mais abrigavam italianos em 1920, os municípios contíguos de Marília, Pompeia e Tupã - todos na zona servida pela E. F. Noroeste - cumpriam o mesmo papel para o caso dos japoneses em 1940, conforme ilustram as Figuras 9 e 10.

FIGURA 9

Principais concentraçôes de italianos no oeste paulista, 1920 (número de indivíduos)

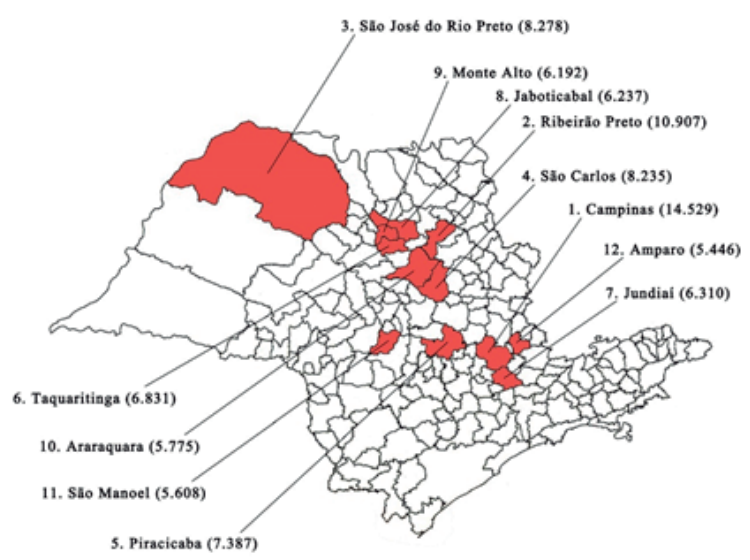

Fonte: Elaboração própria. 
FIGURA 10

Principais concentrações de japoneses no oeste paulista, 1940 (número de indivíduos)

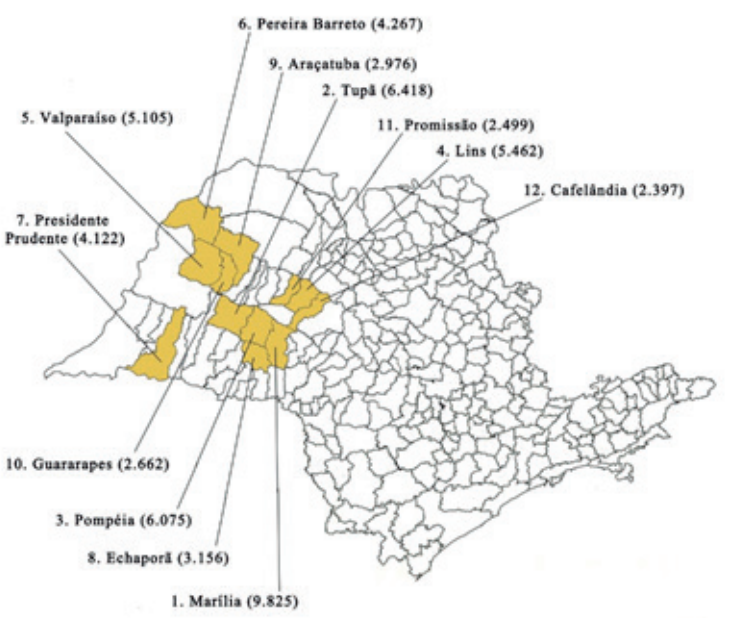

Fonte: Elaboração própria.

\section{Oferta de terras mais produtivas e mais baratas a oeste}

No entanto, grupos que vieram antes (como os italianos) também se estabeleceram em zonas mais distantes, a oeste, porque se sentiram atraídos por áreas onde as terras eram mais baratas e mais produtivas. Monbeig ponderou ser "bem provável que um bom número de imigrantes, depois de curta passagem pelos grandes domínios, abandonassem-nos e partissem para mais à frente, assim como é certo que, na sua chegada, o imigrante dava preferência pelas plantações já em ponto de produção, não sendo atraído pelas derrubadas e plantio" (Monbeig, 1984, p. 174). Tavares de Almeida, por exemplo, observou que "o imigrante, quando chegou a Rio Preto, já compreendia o português. Não veio diretamente de seu país. Só alguns sírios e, mais tarde, os japoneses. As etnias de maior densidade, a italiana, a espanhola e a portuguesa tinham passado em outras zonas" (Almeida 1943, p. 184). Brandi endossa tal ponto de vista ao apurar que os imigrantes não vinham diretamente para a região, assim que desembarcados no porto de Santos ou alojados na Hospedaria dos Imigrantes: "a grande maioria imigratória estabelecida em São José do Rio Preto [...] é oriunda de quatro regiões: Ribeirão Preto, Jaboticabal, Araraquara e São Carlos" (Brandi, 2012, p. 389).

Também foi muito comum que famílias trabalhassem alguns anos como colonos e, à medida que lograssem constituir algum pecúlio, cumprissem o sonho de se tornarem proprietárias. Ora, isto era mais fácil de se realizar em áreas recém-abertas à exploração, mais distantes da capital, onde o preço do alqueire era mais em conta.É por tal razão que encontraremos em 1934 - distante, portanto, do pico da imigração 
FIGURA 11

População italiana em área rural, 1934

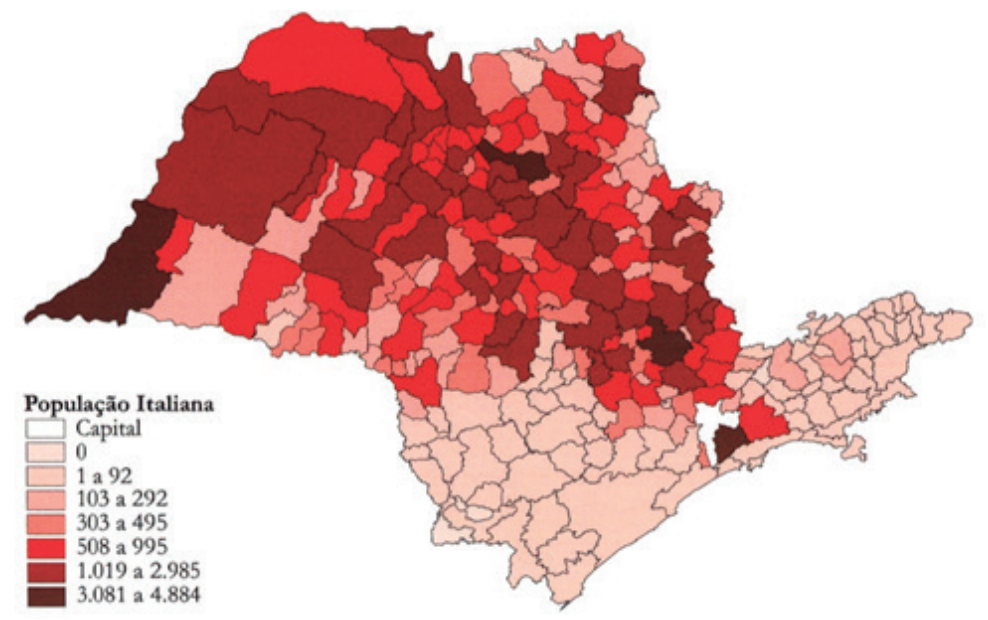

Fonte: Bassanezi et al. (2008).

italiana ocorrido ainda no século XIX - uma concentração razoável de italianos em áreas rurais do extremo oeste do estado, conforme ilustra a Figura 11.

As próprias famílias de imigrantes que haviam sido trazidas para o regime de colonato constituíram a demanda potencial para o mercado de terras mais a oeste do estado. Muitas dessas terras tinham sido simplesmente apropriadas ou adquiridas por famílias de implantação mais antiga, que constituíram a frente pioneira, já aludida anteriormente. Com o passar do tempo, vislumbrou-se a oportunidade de lotear grandes glebas de terra ainda virgem, para justamente atender ao sonho acalentado pelos imigrantes de se tornarem proprietários, como ilustra o anúncio (Figura 12).

De acordo com Monbeig (1984), após a crise de 1929, tal processo só se acirrou, pois os grandes fazendeiros, agrupados em sociedades ou recorrendo a vendedores, logo procuraram compensar suas perdas desfazendo-se de parte de suas terras principalmente em áreas mais distantes. "Como dificilmente encontrariam compradores para grandes extensões de terras, optaram por retalhar as propriedades, já que havia muitos compradores interessados em pequenos lotes, dentre eles imigrantes, trabalhadores de plantações arruinadas ou colonos que sofreram menos com a crise do que seus patrões" (Oliveira, 2009). Do mesmo modo, Lenharo (1986) observou que a crise do café golpeava o latifúndio, o que desencadeou a divisão de várias propriedades e sua venda para pequenos agricultores.

Na região de Presidente Prudente e seu entorno, os loteamentos de grandes glebas em pequenas propriedades constituíram um sistema de vendas a prazo mais dinâmico, especificamente voltado às famílias rurais de imigrantes (e também nacionais) das chamadas “zonas velhas", embaladas pelo sonho de se tornarem proprietárias. 
FIGURA 12

Anúncio da Empresa Paulista de Colonização Ltda.

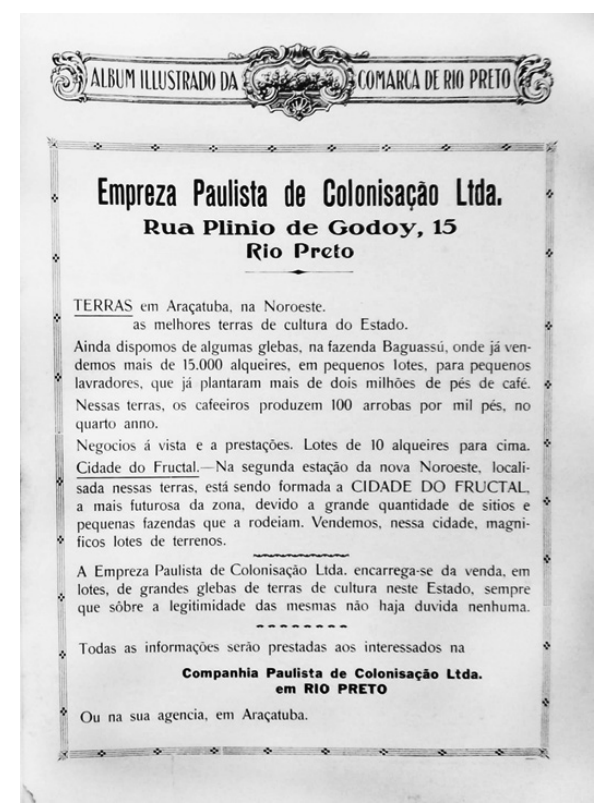

Fonte: Cavalheiro (1929).

Esta procura de terras virgens para o café por pessoas de poucas posses ajuda a explicar o aparecimento dos loteamentos, sem contar as companhias estrangeiras que se formaram com o intuito de adquirir grandes glebas e formar colônias em lotes para localizar os imigrantes de seus países [...]. A busca de solos virgens para o café, a especulação com terras e a colonização pelo loteamento de grandes glebas resumem as características do povoamento da Alta Sorocabana. Os núcleos urbanos surgiram como pontos de apoio para a exploração econômica da região (Abreu, 1972, pp. 37 e 42).

Tome-se como exemplo a trajetória da família Campregher. Antonio chegou ao Brasil solteiro, com trinta anos, em 1888, proveniente de uma pequena aldeia da província de Trento. Instalou-se em São Carlos, como colono, logo se casou com Giuseppina Cecconato, dezessete anos mais nova, nascida na província de Treviso. Em agosto de 1893 nasceu a primeira filha do casal, Elisa. Quando esta tinha apenas quarenta dias, a família decidiu se mudar para Ibitinga, cerca de 130 quilômetros mais a oeste. Quando completava vinte anos, Elisa casou-se nessa mesma cidade com o italiano Francesco Turco, nascido na província de Chieti, que chegou ao Brasil muito jovem. Este, após trabalhar como colono, passou a formar cafezais para outros proprietários rurais. O casal teve oito filhos. Foi somente após a crise de 1930, que Francesco logrou adquirir um sítio de 12 alqueires, onde viveram, criaram seus oito filhos e faleceram (Antonio, em 1952, e Elisa, em 1967). 
A aspiração de adquirir uma propriedade rural, entretanto, nem sempre era bem-sucedida. Domenico Antonio Parizzi nasceu em 1868 em um pequeno distrito (Ceramida), pertencente ao município de Bagnara Calabra, na região da Calábria. Chegou só ao Brasil em 1893, com 24 anos. Quatro anos depois, chegou seu irmão mais velho, Giuseppe, acompanhado de sua esposa e um filho. Em 1900, Domenico se casou em São Carlos com uma italiana (Assunta Sciampi) e logo tiveram o primeiro filho, Felippe, nascido em 1902. Foi também em 1902 que outro irmão de Domenico (Giovanni) chegou da Itália.

Um censo municipal de 1907, realizado em São Carlos, atesta que os três irmãos e suas respectivas famílias formavam na época três casais que, juntos, contavam com dez filhos e residiam na mesma fazenda pertencente à família Arruda Botelho. Eram humildes, analfabetos, e sempre se empregaram no colonato. Em 1922, Felippe, já com vinte anos, casou-se com a filha de um austríaco (Albina Iuga) e permanecia no colonato, três décadas após a chegada de seu pai ao Brasil. Em 1923, o primeiro filho do casal faleceu logo após o parto e foi sepultado em São Carlos. Logo depois toda a família também se transladou para Ibitinga, onde nasceu a primeira filha, Rosa, em 1925. Domenico faleceu em 1951, e sua esposa alguns anos depois, ambos em Ibitinga. Os filhos de Domenico permaneceram em Ibitinga até o início dos anos 50. Embora a família tenha trabalhado no campo por quase seis décadas, esta jamais alcançou a condição de proprietária rural, o máximo que seus membros lograram foi trabalharem como arrendatários ou meeiros.

\section{Estratégias relacionais produzindo efeitos de concentração étnica em determinadas regiões e municípios}

Entre os diferentes grupos étnicos que chegaram ao interior paulista, a maior ou menor valorização do convívio propriamente étnico pelas famílias aqui chegadas também em parte influenciou tanto permanências quanto deslocamentos familiares, direcionando percursos. Redes de solidariedade, associativismo e mesmo a presença de lideranças locais acabaram - mais para alguns grupos do que para outros - produzindo seus efeitos sobre a implantação das famílias no território paulista. O caso mais gritante é o dos japoneses.

De modo muito mais contundente que italianos, espanhóis e portugueses estabelecidos no meio rural, é notável que os colonos japoneses, influenciados por tradições culturais trazidas da terra de origem - em particular, a valorização da educação dos filhos -, tenham logrado se aglutinar e se organizar, mesmo sob o regime de colonato. "Mesmo em fazendas de proprietário brasileiro, quando trabalhavam muitos lavradores de parceria e colonos em grande número, organizava-se uma associação de japoneses" (Uma Epopeia, 1992, p. 209). E a primeira providência da associação 
recém-fundada era justamente organizar uma escola. A existência de escolas exerceu um efeito de concentração, pois provocava mudanças de imigrantes para determinadas localidades, justamente por causa da possibilidade de educar os filhos em estabelecimento onde se ensinava tanto o novo idioma quanto o dos antepassados.

Tal padrão foi depois reforçado pelo apoio do governo japonês em pelo menos três frentes: (a) apoio à instalação e ao funcionamento das escolas; (b) intervenção, associada a companhias de colonização japonesas, no sentido de facilitar a transição do duro regime de colonato à aquisição da pequena propriedade rural, via implantação de colônias ${ }^{10}$; (c) fomento à criação de cooperativas no intuito de viabilizar financeiramente tais colônias (Seabra, 1977, p. 33).

Certamente tais posturas, tanto das famílias emigradas quanto do governo japonês, incentivaram uma intensa mobilidade espacial do grupo (Suzuki, 1969, p. 200), adensando a coesão étnica e o desejo de conviver entre conterrâneos. Daí a consequência de determinados municípios e regiôes do oeste paulista ${ }^{11}$ aglutinarem colônias numerosas de japoneses e descendentes.

Embora portando mais vigor e motivações singulares, a concentração de japoneses não foi ocorrência isolada. Em 1923, uma colônia que reunia alemães da Suábia foi inaugurada no município de Presidente Venceslau, sob a iniciativa de Fritz Keller, agente (alemão) intermediário da Companhia Mendes Campos Filho, grande proprietária de terras no município. Em menos de uma década, a colônia (conhecida como Aymoré), já desde o início formada por proprietários, se adensou abrigando mais de quatro centenas de indivíduos, com os imigrantes germânicos "atraídos agora não apenas pelas facilidades em adquirir uma pequena propriedade, como também por se encontrar, previamente estabelecida, uma colônia de conterrâneos na região" (Soares, 2009, p. 27).

Outros grupos também acabaram elegendo determinados municípios como foco de aglutinação, não tanto pelo deleite do convívio étnico ou pelo empenho de seus governos de origem em acompanhar e facilitar a vida das famílias emigradas, como no caso japonês, mas sobretudo pelo efeito de redes migratórias que em alguns casos se estabeleceram. Pode-se citar como exemplo o caso de sírios e libaneses, cujo fluxo, alheio à política migratória subsidiada praticada pelo governo paulista, sempre dependeu bastante da importação de parentes e conterrâneos (Truzzi, 2008). Estabeleceram-se assim, em determinados municípios do interior, contingentes expressivos de famílias oriundas de localidades específicas, como os procedentes da

10. Tome-se como exemplo a fundação de Bastos e de Álvares Machado, entre outros municípios da região (Abreu, 1972; Takenaka, 2003).

11. Especialmente - mas não exclusivamente - a zona servida pela estrada de ferro Noroeste ao longo dos anos de 1920 e 1930. 
minúscula Kfarhamam em Barretos, Colina e Jaborandi (Drubi, 1998), ou ainda os de Hasbaya, em Bariri (Greiber et al., 1998, p. 251), ambos povoados situados ao sul do Líbano.

De certa forma, como notou Cardoso em relação aos japoneses, "o grupo étnico funcionou como uma grande rede de informação e apoio que facilitou tanto a localização dos imigrantes em núcleos quanto o seu desenvolvimento" (Cardoso, 1995, p. 59).

Mesmo os italianos, bastante volumosos e espalhados territorialmente, não escaparam de certo modo a tal condição, como demonstra o predomínio de mantovanos em Ribeirãozinho (atual Taquaritinga), dos oriundi de Potenza (na Basilicata) em Mococa, de venetos em São José do Rio Pardo (Alvim, 1986, pp. 64-65) e de calabreses nas zonas urbanas de Jaú (Oliveira, 2008) e São Carlos (Truzzi, 2008).

É razoável se supor que a campanha de nacionalização encetada por Vargas no ocaso dos anos 1930, ao minar a organização étnica das colônias (fechando escolas, associações e jornais), tenha desfavorecido os focos de concentração étnica - particularmente de japoneses e dos alemães acima mencionados, ambos chegados mais tardiamente e também mais visados. Na Figura 13, o percurso da família Nagano é ilustrativo a esse respeito. Porém, é também provável que tal efeito (de desconcentração étnica) tenha sido produzido, pelo menos em parte, pelo advento de uma nova geração de filhos de imigrantes, brasileiros, como se notará oportunamente.

FIGURA 13

Percurso da família Nagano
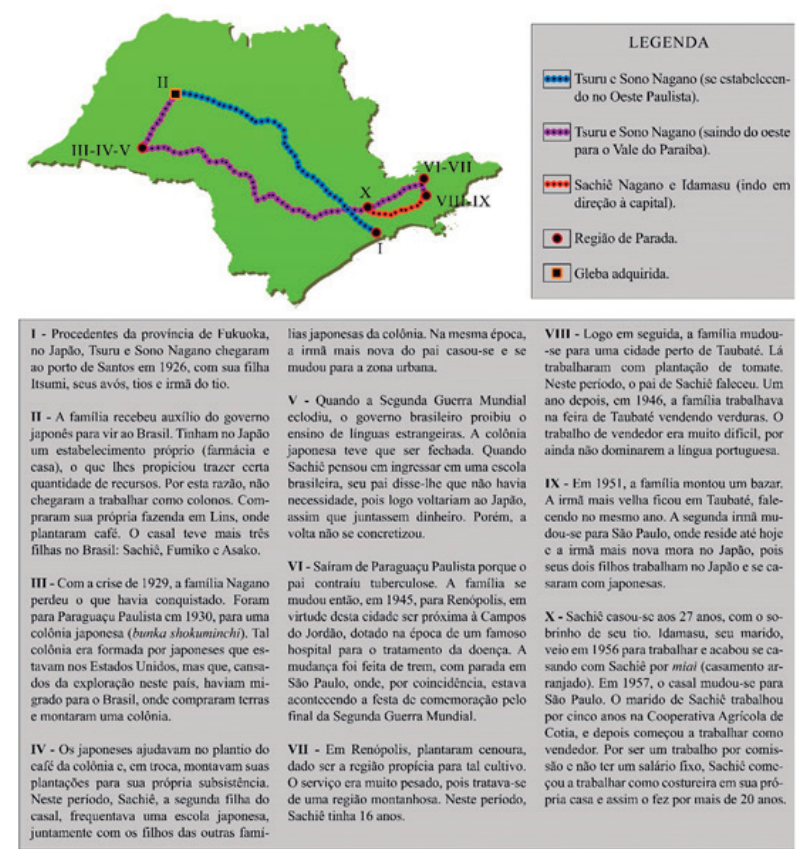

Fonte: Entrevista com Sachiê Nagano. 
Êxodo rural em direção a zonas urbanas de municípios maiores e à capital do estado

Sobretudo a partir da segunda metade dos anos 1930, o esvaziamento demográfico progressivo das zonas rurais conduziu muitas famílias de imigrantes e seus descendentes a tentarem a vida na capital ou em centros urbanos. Voltemos ao caso da família Parizzi. No início dos anos 1950, a família mudou-se para São Paulo, instalando-se em uma vila (cortiço) no bairro da Água Rasa. Em 1950, o filho homem mais velho de Felippe, Domingos, arrumou um emprego na Companhia Antarctica, como entregador de bebidas. Assim que obteve habilitação para conduzir, Domingos mudou de função e casou-se em 1953 com Anna Turco (uma das filhas de Francesco Turco e Elisa Campregher, já mencionados), com quem namorava desde que residia em Ibitinga. Domingos aposentou-se como motorista da Antarctica e faleceu na capital em 1989, dois anos depois de sua esposa Anna ${ }^{12}$ (Figura 14).

FIGURA 14

Percurso das familias Campregher, Turco e Parizzi
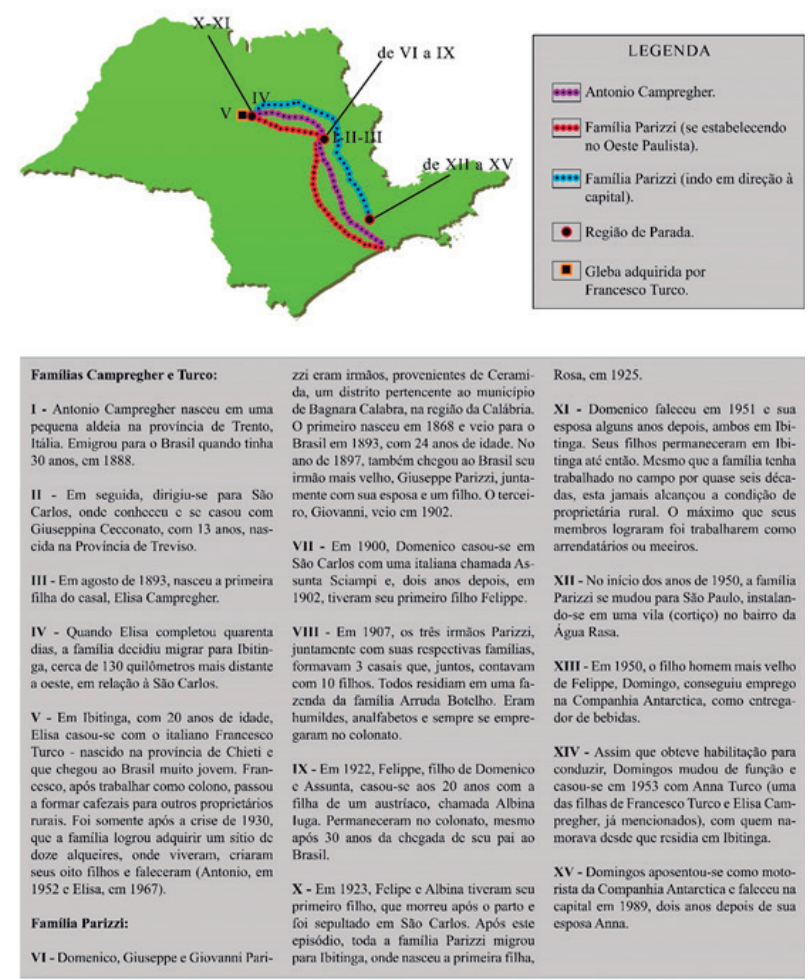

Fonte: Entrevistas com Mario Turco, Deraldino Parizzi e Roseli Parizzi.

12. Ironicamente, após se casar, sua filha mudou-se em 1983 para São Carlos (onde para a família tudo começou, no Brasil), lá residindo até os dias de hoje. 
Tanto o processo inicialmente descrito, de deslocamento de imigrantes para zonas rurais pioneiras, quanto o de urbanização acelerada foram admiravelmente percebidos pelo olhar arguto de Antonio Candido:

Podemos então ver que o café foi, quase sempre, fator de surtos demográficos, que cederam quando a prosperidade por ele determinada não deu lugar a outro tipo de produção ou atividade, mormente as de caráter urbano. Sob esse aspecto é instrutiva a comparação das curvas (demográficas) de São Manuel e Botucatu. Aquela, subindo vertiginosamente para cair depois de modo acentuado, embora a produção de café em arrobas não tenha caído proporcionalmente, indica município monocultor sem outros meios de fixar a população. Esta, mantendo-se ascendente em todas as etapas, revela a importância comercial e industrial logo adquirida pela sede. A esse respeito, é decisiva a comparação dos dados de 1940 e 1950. Foi o decênio da grande prova, em que o surto industrial e a miragem das novas zonas pioneiras atraíram centenas de milhares de trabalhadores e sitiantes das zonas velhas [...]. A impressão resultante é que, nas zonas velhas, os municípios agrícolas, grandes e pequenos, caem demograficamente se não conseguem condições duradouras de urbanização. A urbanização dos centros regionais, como Botucatu, Itapetininga, Tatuí e sobretudo Sorocaba, faz-se à custa das perdas demográficas das zonas rurais tributárias (Candido, 1964, pp. 19-20).

\section{Fracionamento de grandes propriedades decadentes em zonas antigas}

No meio propriamente rural, a crise dos anos 1930 também ocasionou fracionamentos de grandes e antigas propriedades, abrindo novas oportunidades para que famílias de imigrantes pudessem instalar-se como pequenos proprietários. Tal processo tendeu a ocorrer sobretudo em zonas mais antigas e decadentes (portanto mais a leste), nas quais cafeeiros velhos e solos esgotados combinavam-se para deprimir a produtividade dos cafezais.

Nos anos 1930, Milliet captou tal fenômeno em vários municípios do interior paulista, todos eles situados em zonas mais antigas. Referiu-se a Atibaia-Bragança como uma região abandonada pelo café e invadida pela policultura. Notou condições semelhantes em Sorocaba, onde o índice de crescimento da pequena propriedade passou de 100 a 179 em apenas cinco anos, de 1930 a 1935. Sobre Campinas, observou que

[... ] nesta região já o latifúndio constitui francamente uma exceção. E vai desaparecendo com rapidez. Tanto o índice negativo de crescimento (100 para 60), como a porcentagem de sua contribuição para o conjunto bem o revelam. Paralelamente decai a grande propriedade, ambas em benefício das propriedades pequenas e médias [...]. Por outro lado, dentro da mesma região, Jundiaí é hoje um centro industrial importante e, do ponto de vista agrícola, 
zona fruticultora por excelência. A região apresenta portanto todos os caracteres favoráveis ao desenvolvimento da pequena propriedade: boas terras, comunicações fáceis, centros consumidores próximos, ausência de culturas extensivas (Milliet, 1939, pp. 87-89).

No estado de São Paulo, provavelmente a experiência mais relevante no sentido de retalhar antigas propriedades foi a da Caic, Companhia de Agricultura, Imigração e Colonização. Fundada em 1928, como Companhia Geral de Imigração e Colonização do Brasil (CGICB), por acionistas da Companhia Paulista, o objetivo inicial da empresa era o de fornecer braços à agricultura, inclusive abrindo espaços para o avanço dos trilhos da estrada de ferro. Entretanto, vinda a crise de 1929, a CGICB assumiu a tarefa de lotear grandes latifúndios de café, sobretudo na zona de Ribeirão Preto. Nessa nova fase de seu trabalho de colonização, operou inicialmente nas chamadas “zonas velhas”, dentro da área de atuação da Companhia Paulista, mas logo seus empreendimentos se estenderam a outras regiões do estado.

Em outubro de 1934, a empresa mudou seu nome para Companhia de Agricultura, Imigração e Colonização (Caic), mais adaptado à sua nova atuação, focada no loteamento de pequenas propriedades voltadas à policultura de mão de obra familiar.

Segundo Carneiro (1985), as terras foram vendidas com muita facilidade, seus negócios prosperaram, o que fez com que a empresa ampliasse seus investimentos rapidamente. Com o passar dos anos a Companhia deixou de atuar somente na “Zona Velha” e por fim acabou estendendo seus negócios a todas as regiões do Estado: Mogiana, Paulista, Sorocabana, Noroeste e Araraquarense.

Ao longo de seus 33 anos de atuação, apenas a Caic atingiu a marca de 8 mil lotes de terras vendidos, exercendo influência na fundação de vários municípios nucleados a partir das sedes de grandes fazendas por ela loteadas ${ }^{13}$.

\section{Busca de oportunidades para os filhos}

A partir dos anos 1930, 1940 e 1950, também não foi incomum que famílias de imigrantes se deslocassem de áreas mais remotas do interior para a capital ou para municípios mais a leste na busca de oportunidades para seus filhos estudarem ou mesmo se casarem dentro da colônia. Há muitos exemplos nesse sentido. Entre japoneses, grupo que se caracterizou por uma inserção inicial massivamente rural,

13. O município de Adamantina, situado entre Presidente Prudente e Araçatuba, é um exemplo. Em 1937, a Caic iniciou a colonização das terras de propriedade da companhia canadense Boston Cattle Company, compreendidas no espigão do Feio-Aguapeí, ao longo do prolongamento da Companhia Paulista de Estradas de Ferro. Foram abertas várias estradas de penetração e, dois anos depois, a Caic procedeu à derrubada de 40 alqueires de matas, para formação do patrimônio. 
Cardoso observou que as exigências de "uma escolaridade que só podia ser obtida na cidade $[. .$.$] assomava claramente à consciência dos imigrantes, pois o motivo que$ mais frequentemente indicam para justificar a transferência para a cidade consiste justamente na necessidade de enviar os filhos à escola” (Cardoso, 1995, p. 137).

Também famílias judaicas, que inicialmente mascatearam e abriram lojas pelo interior, tenderam depois a se concentrar na capital, onde as possibilidades matrimoniais para os filhos se conservarem na religião eram mais promissoras. Considere-se a trajetória dos irmãos poloneses Pejsach e Moisés Muszkat. O primeiro chegou ao Brasil em 1929, com 22 anos e estabeleceu-se em São Carlos, onde se empregou como funcionário de Salomão Schevs, um comerciante de tecidos de origem lituana já bem estabelecido na cidade. Três anos depois, chegou Moisés. Os dois irmãos atuaram como mascates, vendendo de porta em porta (de bicicleta e de charrete) e, a partir de São Carlos, também percorriam de trem as zonas da Douradense e da Alta Paulista. Em 1933 conseguiram eles próprios se estabelecer com uma loja, a Casa Progresso, na rua de maior comércio de São Carlos. Encerrada a fase de mascateação, Moisés casou-se no mesmo ano com Sônia, uma prima que importou da Polônia, com quem teve três filhos nascidos em São Carlos. Em 1942, Moisés decidiu mudar-se para São Paulo, "para aumentar a interação com a comunidade judaica” e para ampliar as oportunidades de estudo para os filhos. $\mathrm{Na}$ capital tornou-se um empresário bem-sucedido, ao fundar uma loja de tecidos na rua Santa Ifigênia, depois uma loja de tapetes (O Rei dos Tapetes) no Bom Retiro, depois uma construtora e, ainda mais tarde, um banco. Todos os filhos de Moisés e Sônia (os três nascidos em São Carlos mais um que já nasceu em São Paulo) casaram-se na colônia judaica. Pejsach permaneceu solteiro até 1946, teve quatro filhos, mas ficou em São Carlos, onde faleceu em 1982. Como a colônia judaica em São Carlos era bem menor, composta por apenas cerca de uma dezena de famílias, é significativo que apenas um dos filhos de Pejsach tenha se casado na colônia, justamente aquele que saiu de São Carlos e foi residir na capital (Figura 15).

Outra trajetória pesquisada, agora de um libanês, ilustra as diversas fases da atividade empresarial (de mascate a industrial), bem como a decisão final de se estabelecer na capital, em parte pelo anseio de ver os filhos formados (Figura 16).

A resultante final de tais processos acima descritos aponta para certa dinâmica referente à implantação de grupos migratórios no território paulista, que pode ser condensada no mapa a seguir (Figura 17).

É nesse sentido que se torna apropriado utilizar o conceito que denomino "percursos migratórios familiares". Ele procura descrever as sucessivas etapas definidas pela mobilidade espacial que tais famílias de imigrantes tiveram que enfrentar, desde sua saída da terra de origem. 
FIGURA 15

Percurso da familia Muszkat

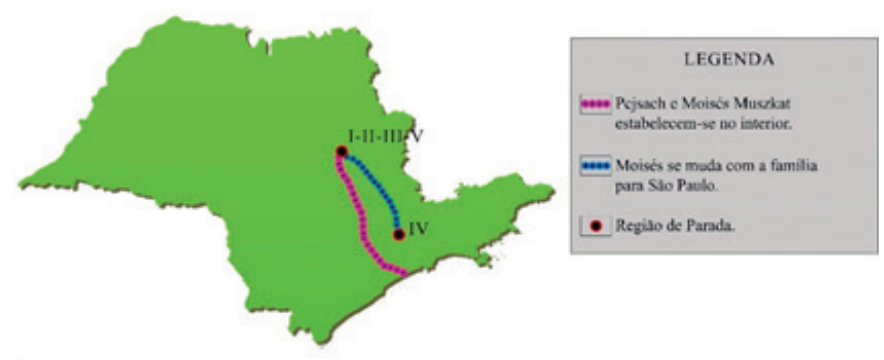

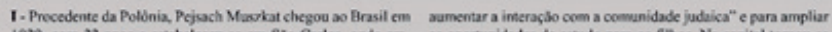

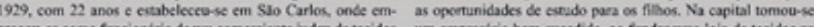

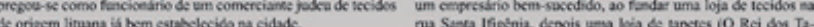

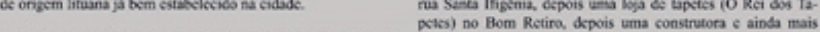

11 - Trts abos depois, chegou scu imlo Mois's Muscdat. Os

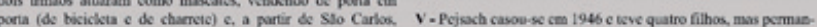

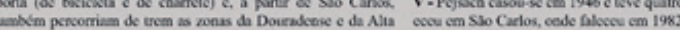
Pauliste.

III - Em 1933 coeswguiras elos proprios we esabelectrom com

uma koja, a Casa Proprowe, a na de maior comércio de S\$o

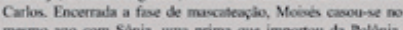

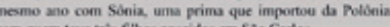

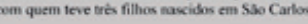

IV - Em 1942, Moisés decidia modar-se para Slo Paula, ppern

Fonte: Entrevista com Estevão Muszkat.

FIGURA 16

Percurso da familia Gastin

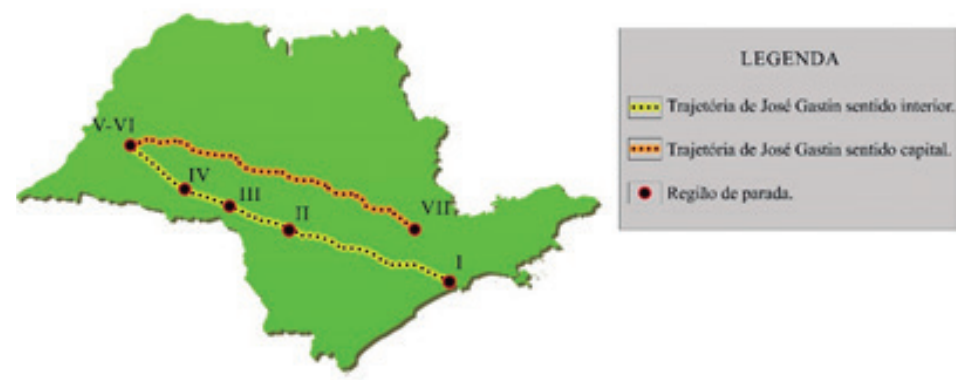
1- Procederte do Lituso, chcyos ao porto de Santos no dia 2 de VI - Em 1928, cempsos uea miquina almal pura beneficiar aoverehro de 1902 , coen mans de 17 anos de itadc.

11 - Foi logo para Avark, onde sous imblos tinhum cemircio.

III - Após oino dias, mudouse para Salo Grande, para masca. Providente Bemantos

tear. Josk resebia mancadorias dos imblos pura depois resur-

ei-ks com o dinkeito que ganhava. Dex asus depobs de su chepala, em 191

IV - Em 1914, madoo-se parz Palmital. Necta cidade se eualeloceu e abriu um botequin:

V - No ano de 1923, a farmila modos-se para Presidenee Ber-

ausdex, onde bodos os seus fillos aasceram. O municipio era

posso urbsaizablo na iposa. Joot moetou uma loja de tociblos

de gincros alimansicion.

Fonte: Greiber et al. (1998). 
FIGURA 17

Dinâmica da implantação de grupos migratórios no território paulista

A Oeste:

quanto mais tarde a chegada, mais a Oeste.

terras mais baratas atraem familias que desejam se tornar proprietárias.
A Leste:

éxodo rural urbano em direção à capital ou municipios maiores.

fracionamento de propriedades decadentes situadas $\mathrm{em}$ zonas mais antigas.

ampliar as oportunidades dos filhos estudarem (ou se casarem).

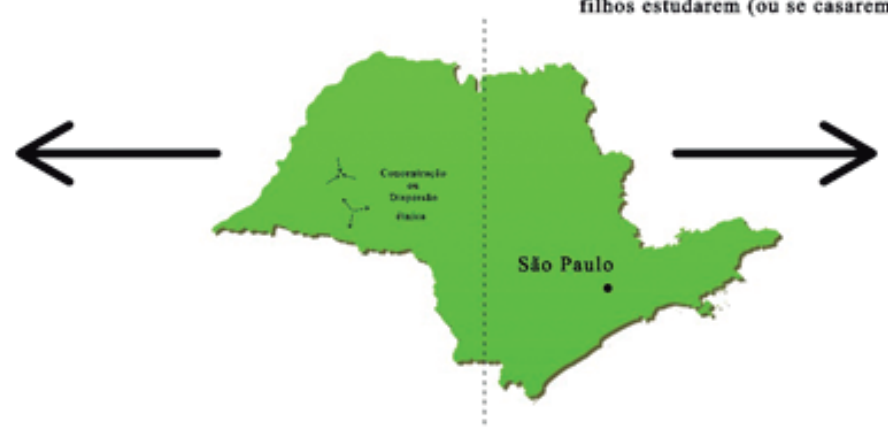

Fonte: Elaboração própria.

FIGURA 18

Percurso da familia Zerbato
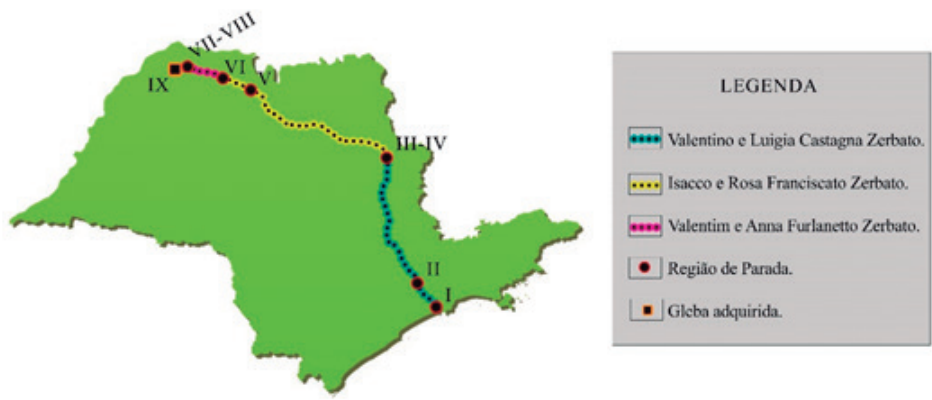

\begin{tabular}{|c|c|c|}
\hline $\begin{array}{l}\text { 1- Originários da comuna de Valdagno, } \\
\text { provincia de Vicenza, Valentino Zerbato e } \\
\text { Luigia Castagna Zerbato embarcaram com } \\
\text { scus } 8 \text { fillos (Bcniamino, Paolo, Guglict- } \\
\text { mo, lsacco, Maddalena, Maryherita, Catte- } \\
\text { rina e Anna) no vapor Minas que, os trouxe } \\
\text { de Génova ao porto de Santos, onde desem- } \\
\text { barcaram em } 8 \text { de janeiro de } 1897 \text {. }\end{array}$ & $\begin{array}{l}\text { V - Isacco mudou-se com a familia para } \\
\text { Såo José do Rio Preto, na fazenda de Ber- } \\
\text { nardino de Campos, em meados de 1918, a } \\
\text { fim de trabalhar como "retirciro" de Icice. } \\
\text { Neste municipio teve mais } 5 \text { filhos: Valen- } \\
\text { tim, Josk, Aparecida, Luiza e Laurita. } \\
\text { VI - Em 1947, Isaceo, seus filhos e esposa } \\
\text { foram trabalhar na fayenda dos Bassan, em }\end{array}$ & 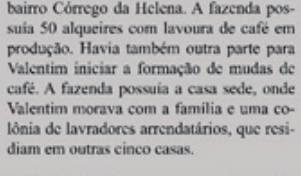 \\
\hline $\begin{array}{l}\text { II - De Santos, rumaram à Hospedaria dos } \\
\text { Imigrantes, onde permaneceram por alguns } \\
\text { dias, à espera do contratante. } \\
\text { III - Foram contratades para trabalhar }\end{array}$ & $\begin{array}{l}\text { Bálsamo. Arrendaram uma lavoura de } 40 \\
\text { mil pés de cafe para cultivar. O outros } \\
\text { filhos constituiram suas familias e arrenda- } \\
\text { ram lavouras de café na regiâo de Sto José } \\
\text { do Rio Preto e cidades adjacentes como }\end{array}$ & $\begin{array}{l}\text { VIII - Scus irmâos se scpararam, tomando } \\
\text { rumos diferentes, Isacco, o pai, permane- } \\
\text { ceu morando na Fazenda dos Bassan, em } \\
\text { Bálsamo. }\end{array}$ \\
\hline & & IX - Em 1968, Valentim comprox \\
\hline $\begin{array}{l}\text { Cabras, de Manoel Amasto, em Santa Rita } \\
\text { do Pases Quatro. Valentino e Luigia fica- } \\
\text { ram neste municipio até a morte. } \\
\text { IV - Isacco, um dos filhos de Valentino e } \\
\text { Luigia, casou-se com Rosa Franciscato, } \\
\mathrm{em} 3 \text { de agosto de } 1908 \text { c teve } 5 \text { filhos: Fio- } \\
\text { relo, Aurelio, Nello, Orestes e Armando. }\end{array}$ & $\begin{array}{l}\text { VII - Valentim, um dos fillos de Isacco e } \\
\text { Rosa, casou-se com Anna Furlanetto, cm } \\
\text { julho de } 1947 \text { e juntos tiveram } 3 \text { filhos: } \\
\text { braac, Clarice e Orides. Em 1958, migrou } \\
\text { para Vilória Brasil, para trabalhar como ad- } \\
\text { ministrador na Fazenda Santa Luria, no }\end{array}$ & $\begin{array}{l}\text { no mesmo cspaço } \mathrm{cm} \text { que trabalhava. O } \\
\text { sitio foi adquirido junto a um dos immäos da } \\
\text { familia Ognibeni que, após of falecimento } \\
\text { do patriarca familiar, dividiu a facenda da } \\
\text { familia em sitios de } 10 \text { alqueires. Valentim } \\
\text { comprou o sitio de um desses imm3os, José } \\
\text { Ognibeni. }\end{array}$ \\
\hline
\end{tabular}

Fonte: Entrevistas com Valentim e Carlos Zerbato. 
Sugere-se que tais percursos sejam assinalados por pontos de inflexão, que podem significar tanto a decisão de emigrar, quanto a decisão por um novo deslocamento familiar, ou ainda o estabelecimento mais duradouro de uma determinada família em um determinado contexto.

Os pontos de inflexão obedecem às estratégias familiares, tecidas e avaliadas em termos de oportunidades (de se deslocar ou de permanecer), com base nas informações disponíveis às famílias migrantes e seus descendentes e fornecidas por agentes de propaganda, parentes, conterrâneos, empresas de loteamento de imóveis, tanto rurais quanto urbanos etc.

Nossa hipótese é que influenciam a definição de tais pontos de inflexão e, por decorrência, tais percursos migratórios: (a) a expectativa de um melhor emprego e consequente busca por um padrão de renda familiar mais elevado (evidenciados pela alta mobilidade dos colonos entre fazendas, influenciada por sua vez pela permissão ou não para criar animais e cultivar pequenas lavouras de subsistência, de praticar cultura intercalar, de se relacionar de modo satisfatório com o patrão etc.); (b) os limites impostos pela capacidade de reprodução familiar em uma dada situação; (c) a possibilidade de aquisição de uma propriedade rural ou de um imóvel urbano; (d) a oportunidade de alguém da família se inserir em empregos na indústria ou no comércio, ou ainda montar um negócio próprio; (e) a expectativa de melhor superar dificuldades quando em convívio étnico; (f) as alterações na estrutura e autoridade familiar, processos de reunificação familiar (ou, ao contrário, de casais jovens se tornarem independentes da tutela patriarcal);(g) a busca de oportunidades para filhos estudarem ou se casarem.

Embora tal modelo seja aqui aplicado especificamente a trajetórias de famílias imigrantes estrangeiras, é razoável se supor que o mesmo possa também fazer sentido, ao menos em certos aspectos, a outros grupos sociais presentes no estado de São Paulo à mesma época, como imigrantes nacionais provenientes de outros estados, estratos da população negra egressa do regime escravista, ou ainda de brasileiros brancos.

Trata-se também de percursos com características intergeracionais, isto é, que são vivenciados por gerações sucessivas ${ }^{14}$, o que traz considerações do feitio que Telles e Cabanes apontaram em relação ao contexto urbano da capital paulista: "com base em entrevistas biográficas, tratou-se de apreender essas modulações de tempo-espaço nos percursos dos indivíduos e suas famílias, também cifradas nas defasagens e diferenças entre gerações” (Telles e Cabanes, 2006, p. 19). Para tanto, é interessante analisar mais um percurso migratório familiar, dentre outros obtidos na bibliografia e em entrevistas realizadas no interior paulista. 
É interessante notar que neste caso, cada geração, a seu tempo, se deslocou espacialmente: Valentino e Luigia, de Vicenza, na Itália, para Santa Rita; Isacco e Rosa, de Santa Rita para São José do Rio Preto e depois Bálsamo; e Valentim e Anna, de Bálsamo para Vitória Brasil. Mais que isso, nesse caso particular, o sonho acalentado da aquisição da propriedade rural persistiu ao longo de pelo menos três gerações, até ser finalmente concretizado.

Entretanto, é oportuno observar que pode haver também percursos de famílias de imigrantes muitas vezes construídos com base em rupturas e dissonâncias que a própria transição geracional pode acarretar. Como exemplo, Ruth Cardoso, ao apontar um conjunto significativo de contrastes entre isseis e nisseis em termos de sociabilidade, escolarização, profissionalização etc. (que inclusive muitas vezes incluiu a mudança domiciliar rural-urbana), concluiu que: "o nissei se distingue do issei não só como geração mas também como um grupo que participa diversamente do universo cultural tradicional" (Cardoso, 1995, p. 133).

\section{Considerações Finais}

Em São Paulo, os condicionantes impostos por uma fronteira agrícola em contínua expansão até pelo menos a primeira metade do século passado, aliados às vicissitudes impostas pela retração econômica e esvaziamento rural de certas áreas a partir dos anos 1930, determinaram um intenso deslocamento de famílias e indivíduos no território. Procuramos explorar então justamente a racionalidade de tais implantações iniciais e deslocamentos sucessivos, entendidos aqui, de um ponto de vista sociológico, como ações sociais.

Embora pouco exploradas aqui, não resta dúvida de que tais deslocamentos se inscreveram em um contexto de políticas governamentais mais gerais, cuja menção não pode ser omitida: (a) a política migratória levada a cabo pelo estado paulista que, informada por um ideal de branquitude, privilegiou determinados grupos e restringiu outros; (b) os estímulos à produção agrícola direcionados à grande propriedade rural cafeeira, pelo menos até 1930; (c) especialmente, os investimentos em transporte (inicialmente privado e depois estatal), tanto marítimo (via subsídio, para a vinda de imigrantes), quanto ferroviário (que viabilizaram a exploração econômica de áreas antes desconectadas da exploração agrícola para o mercado mundial); (d) a partir dos anos 1930, a adoção de um regime de cotas pela Constituinte de 1934 (cujo alvo preferencial, porém não exclusivo, foram os japoneses) e, em seguida, as restrições às organizações étnicas impostas pelo regime varguista.

No interior de tal enquadramento, a dinâmica de distribuição dos grupos estrangeiros no interior paulista foi ainda condicionada pela disponibilidade de terras 
férteis e relativamente abrigadas da geada (acima do Trópico de Capricórnio), e dependeu, em sua concretude, de alguns fatores e processos aqui explorados que simultaneamente interagiram entre si:

- O deslocamento geográfico do investimento das elites econômicas e a consequente expulsão de populações marginalizadas (índios, posseiros, quilombolas) para zonas mais distantes ou incorporação dos mesmos como agregados (inclusive com apoio da ordem jurídica da época).

- O timing da chegada que condicionou a implantação dos vários grupos de imigrantes em zonas já abertas à exploração agrícola e mais carentes de mão de obra, acarretando, como regra geral, que grupos que vieram depois tenham se estabelecido em zonas mais distantes da capital ${ }^{15}$.

- Os processos de mobilidade geográfica dos colonos, via migrações sucessivas, aspirando a: (i) encontrarem condições de trabalho e remuneração mais vantajosas; (ii) estabelecerem-se como pequenos proprietários em zonas de fronteira onde a terra é mais barata (iii) em alguns casos, usufruírem da convivência entre conacionais; - os dois primeiros condicionando, de modo geral, deslocamentos mais a oeste.

- Os processos decorrentes de êxodo rural, sobretudo após a crise de 1930, e de busca de oportunidades para os filhos, em direção a zonas urbanas de municípios maiores e à capital do estado condicionando deslocamentos no sentido inverso, mais a leste.

Cada censo capta uma fotografia meramente estática, mas que na verdade é a resultante, em um determinado momento, de cada um desses processos agindo simultaneamente. Em seu conjunto, os percursos migratórios intergeracionais aqui referidos nos sugerem uma face mais dinâmica e ativa do processo de implantação e acomodação de famílias de origem imigrante no território paulista, até então pouco explorada pela análise, em certo sentido ilusória, que os recenseamentos, mesmo que tomados em seu conjunto, tendem a nos oferecer.

15. O que por sua vez trouxe consequências importantes. Assinale-se, a título de exemplo, duas delas. Em primeiro lugar, o problema da baixa visibilidade social para grupos que se assentaram mais distantes da capital. O exemplo clássico são os espanhóis (para uma explicação mais abrangente, consultar Truzzi e Palma, 2014). Não obstante, note-se que os japoneses, embora tenham chegado tardiamente, não padeceram do mesmo fenômeno, inclusive (mas não somente) por razões fenotípicas. Em segundo lugar, é notável, a partir dos anos 1930, a maior facilidade que tiveram os descendentes de imigrantes em abarcar postos na política local nas zonas mais novas, porque, nestas, estratos de imigrantes relativamente bem-sucedidos em boa medida já se constituíram como elites. Em zonas mais antigas, ao contrário, a competição por poder político local foi mais aguerrida porque já havia descendentes de elites nativas estabelecidas fazia mais tempo nas arenas da política local (Truzzi et al., 2012). 


\section{Referências Bibliográficas}

Abreu, Dióres S. (1972), Formação histórica de uma cidade pioneira paulista: Presidente Prudente. Presidente Prudente, Faculdade de Filosofia, Ciências e Letras.

Almeida, A. Tavares. (1943), Oeste paulista: a experiência etnográfica e cultural. Rio de Janeiro, Alba.

Alvim, Zuleika M. F. (1986), Brava Gente! Os italianos em São Paulo, 1870-1920. São Paulo, Brasiliense.

BACELlar, Carlos. (1999), Na estrada do Anhanguera: uma visão regional da história paulista. São Paulo, Humanitas/Faculdade de Filosofia, Letras e Ciências Humanas da Universidade de São Paulo.

Bassanezi, Maria et al. (2008), Atlas da imigração internacional de São Paulo: 1850-1950. São Paulo, Editora da Unesp.

Brandi, Agostinho. (2012), São José do Rio Preto 1894-1907: o ciclo dos intendentes e a criação da comarca. São José do Rio Preto, THS.

Candido, Antonio. (1964), Os parceiros do Rio Bonito. Rio de Janeiro, José Olympio.

CARDoso, Ruth L. (1995), Estrutura familiar e mobilidade social: estudo dos japoneses no Estado de São Paulo. São Paulo, Kaleidos-Primus.

Carneiro, Honório. (1985), A Caic: Companbia de Agricultura, Imigração e Colonização: 1928-1961. São Paulo, dissertação de mestrado, Fundação Escola de Sociologia e Política de São Paulo.

Carvalho, Diego. (2009), Trabalho e conflito na Noroeste do Brasil: a greve dos ferroviários de 1914. São Paulo, dissertação de mestrado, Faculdade de Filosofia, Letras e Ciências Humanas da Universidade de São Paulo.

Cavalheiro, A. (org.). (1929), Album Illustrado da Comarca de Rio Preto 1927-1929. São Paulo, Duprat/Mayença.

Coelho, Hercídia. (2005), Imigração sírio-libanesa em Franca. Franca, Editora da Unifran.

Drubi, Syria. (1998), Raizes de Jaborandi. Barretos, Gráfica Soares Barretos.

Ellis JR., Alfredo. (1960), Tenente-coronel Francisco da Cunha Bueno: pioneiro da cafeicultura no Oeste Paulista. São Paulo, Linográfica.

Fausto, Boris. (1991), Historiografia da imigração para São Paulo. São Paulo, Sumaré.

Greiber et al. (1998), Memórias da imigração: libaneses e sírios em São Paulo. São Paulo, Discurso.

GRIBAUDI, Maurizio. (1987), Itineraires ouvriers: espace et groupes sociaux à Turin au début du siècle. Paris, EHEss.

Hall, Michael. (1969), The origins of mass immigration to Brazil, 1871-1914. Nova York, tese de doutorado, Columbia University.

Holloway, Thomas. (1984), Imigrantes para o café. Rio de Janeiro, Paz e Terra. 
Leite, Silvia. (2007), Os italianos no poder, cidadãos catanduvenses de virtude e fortuna: 19181964. Araraquara, tese de doutorado, Faculdade de Ciências e Letras da Universidade Estadual de Araraquara.

Lenharo, Alcir. (1986), Colonização e trabalho no Brasil: Amazônia, Nordeste e Centro-Oeste. Campinas, Editora da Unicamp.

Martins, José. (1996), O cativeiro da terra. São Paulo, Hucitec.

Matos, Odilon. (1974), Café e ferrovias: a evolução ferroviária de São Paulo e o desenvolvimento da cultura cafeeira. São Paulo, Alfa-Ômega.

Milliet, Sérgio. (1939), Roteiro do café e outros ensaios. São Paulo, Coleção Departamento de Cultura, vol. xxv.

Monbeig, Pierre. (1984), Pioneiros e fazendeiros de São Paulo. São Paulo, Hucitec/Polis.

Oliveira, Flávia. (2008), Impasses no Novo Mundo: imigrantes italianos na conquista de um espaço social na cidade de Jaú (1870-1914). São Paulo, Editora da Unesp.

Oliveira, Giani. (2009), Imigração na década de 1930: o trabalho desenvolvido pela Companhia de Agricultura, Imigração e Colonização (Caic) no estado de São Paulo. Disponível em http:// www.pph.uem.br/cih/anais/trabalhos/537.pdf, consultado em 11/2/2019.

Oliveira, Sérgio. (2002), Os espanhóis. Sorocaba, тсм Comunicação.

Pinto, Álvaro V. (1973), El pensamiento critico en demografia. Santiago de Chile, Centro Latinoamericano de Demografia (Celade).

Sauvy, Alfred. (1970), La population. Paris, Presses Universitaires de France.

SeAbra, Manoel G. (1977), As cooperativas mistas do estado de São Paulo: estudo de geografia econômica. São Paulo, tese de doutorado, Faculdade de Filosofia, Letras e Ciências Humanas da Universidade de São Paulo.

SoAres, Bruno Pinto. (2009), Germanismo e nazismo na colônia alemã de Presidente Venceslau (1923-1945). Assis, dissertação de mestrado, Faculdade de Ciências e Letras da Universidade Estadual Paulista.

Suzuki, T. (1969), “Narrative part”. In: The Japanese immigrant in Brazil. Tóquio: University of Tokyo, vol. 2.

Takenaka, Edilene M. M. (2003), Raizes de um povo: a colônia japonesa de Álvares Machado. Presidente Prudente, dissertação de mestrado, Faculdade de Ciências e Tecnologia da Universidade Estadual Paulista.

Telles, Vera \& Cabanes, Robert. (2006), “Introdução”. In: Telles, Vera \& Cabanes, Robert (orgs.). Nas tramas da cidade: trajetórias urbanas e seus territórios. São Paulo, Humanitas, pp. 11-28.

Truzzi, Oswaldo Mario Serra. (2008), Patrícios: sírios e libaneses em São Paulo. São Paulo, Editora da Unesp.

Truzzi, Oswaldo Mario Serra \& Follis, Fransérgio. (2012), A ocupação dos sertões de Araraquara: das sesmarias e apossamentos à Lei de Terras de 1850. São Carlos, Editora da EdufsCar. 
Truzzi, Oswaldo Mario Serra \& Palma, Rogério. (2014), “A imigração espanhola no interior paulista: inferências a partir de um estudo de caso". Contemporânea: Revista de Sociologia da UFSCar, 2 (4): 461-480.

Truzzi, Oswaldo Mario Serra et al. (2012), "Mudança de fronteiras étnicas e participação política de descendentes de imigrantes em São Paulo”. RBCS, 80 (27): pp. 135-256.

UMA EPOPELA MODERNA: 80 anos da imigração japonesa no Brasil. (1992), São Paulo, Hucitec/ Sociedade Brasileira de Cultura Japonesa.

\section{Entrevistas realizadas}

Carlos Zerbato (agosto de 2017).

Deraldino Parizzi (janeiro de 2019).

Estevão Muszkat (janeiro de 2019).

Mario Turco (dezembro de 2018).

Roseli Parizzi (setembro de 2018).

Sachiê Nagano (agosto de 2017).

Valentim Zerbato (agosto de 2017).

\section{Resumo}

Percursos migratórios intergeracionais e dinâmicas de implantação de imigrantes estrangeiros no oeste paulista (1880-1950)

Do que dependeu a implantação geográfica dos diversos contingentes de imigrantes que se estabeleceram no interior paulista, entre as décadas de 1880 e 1950? Este artigo busca responder a tal questão. Para tanto, parte do reconhecimento da existência de uma fronteira em contínua expansão no território paulista, que significou também uma contínua mobilidade das famílias imigrantes. A partir de uma série de fontes documentais, censitárias e da realização de várias entrevistas, elaborou-se então um modelo para se explicar a implantação geográfica dos imigrantes, estruturado segundo determinadas variáveis. Conclui-se que uma fronteira agrícola em contínua expansão, aliada à retração econômica e ao esvaziamento rural de certas áreas a partir dos anos 1930 determinaram um intenso deslocamento de famílias e indivíduos no território.

Palavras-chave: Percursos migratórios; Fronteira agrícola; Deslocamentos populacionais, Estratégias familiares; São Paulo. 


\section{Abstract}

Multigenerational Migratory Paths and Settling of Foreign Immigrants in Western São Paulo (1880-1950)

What did the geographical implantation of the various contingents of immigrants who settled in the interior of São Paulo between the 1880s and 1950s depend on? This article seeks to answer this question. It starts with the recognition of an expanding agricultural frontier in the territory of São Paulo, which also meant a continuous mobility of immigrant families. Based on a series of documentary and census sources, as well as on several interviews, we elaborate a model to explain the geographical implantation of the immigrants according to some variables. We conclude that a continuously expanding agricultural frontier, together with the economic retraction and rural emptying of certain areas since the 1930s, have led to an intense displacement of families and individuals in the territory.

Keywords: Migratory trajectories; Agricultural frontier; Populational displacements; Family strategies; São Paulo.

Texto recebido em 18/2/2019 e aprovado em 7/10/2019.

DOI: $10.11606 / 0103-2070 . t s .2019 .154911$

oswaldo mario Serra truzzi é professor titular sênior do Programa de Pós-graduação em Sociologia da Universidade Federal de São Carlos e pesquisador do CNPq.E-mail: truzzi@ufscar.br. JOÃo PEDRo volante é mestrando do Programa de Pós-graduação em Sociologia da Universidade Federal de São Carlos. E-mail: joaopedrovolante@gmail.com. 